\title{
Uptake and Reduction of Hexavalent Chromium by Aspergillus niger and Aspergillus parasiticus
}

\author{
Shugaba $\mathrm{A}^{1 *}$, Buba $\mathrm{F}^{1}$, Kolo $\mathrm{BG}^{2}$, Nok $\mathrm{AJ}^{3}$, Ameh $\mathrm{DA}^{3}$ and Lori JA \\ ${ }^{1}$ Department of Biochemistry, Faculty of Science, University of Maiduguri, Maiduguri, Nigeria \\ ${ }^{2}$ Department of Chemistry, Faculty of Science, University of Maiduguri, Maiduguri, Nigeria \\ ${ }^{3}$ Department of Biochemistry, Faculty of Science, Ahmadu Bello University, Zaria, Nigeria \\ ${ }^{4}$ Department of Chemistry, Faculty of Science, Ahmadu Bello University, Zaria, Nigeria
}

\begin{abstract}
The uptake and reduction of $\mathrm{Cr}(\mathrm{VI})$ by Aspergillus niger and $A$. parasiticus was studied in this journal. After 96 hours of growth, the culture solutions spiked with an initial dichromate concentration of $20 \mathrm{mg} / \mathrm{l}$, were completely decolorized and had residual $\mathrm{Cr}(\mathrm{VI})$ concentrations of only $0.74 \pm 0.55$ and $1.69 \pm 0.29 \mathrm{mg} / \mathrm{l}$ in $A$. niger and $A$. parasiticus cultures representing $\mathrm{Cr}(\mathrm{VI})$ removal of $96.3 \%$ and $91.6 \%$, respectively. In the $A$. niger culture, significantly $(\mathrm{P}<0.01)$ lower $\mathrm{Cr}(\mathrm{VI})$ concentrations were observed within 72 hours of growth compared to those of $A$. parasiticus, but in both cultures complete removal was almost achieved by 144 hours of growth. The rate of $\mathrm{Cr}(\mathrm{VI})$ removal was $0.21 \pm 0.09 \mathrm{mgl}^{-1} \mathrm{hr}^{-1}$ and $0.20 \pm 0.07 \mathrm{mgl}^{-1} \mathrm{hr}^{-1}$ for $A$. niger and $A$. parasiticus, respectively. Cellular concentrations of $\mathrm{Cr}(\mathrm{VI})$ in the two fungi increased significantly $(\mathrm{P}<0.05-0.001)$ with increasing concentrations of the dichromate treatments. Although tannic acid as sole source of carbon and energy gave significantly lower $\mathrm{Cr}(\mathrm{VI})$ removal than glucose $(P<0.001)$ and acetate $(P<0.01)$, it supported the removal of about $85.0 \%$ and $68.8 \%$ of the metal ion by $A$. niger and $A$. parasiticus, respectively. The active mycelia of both fungi showed significantly $(P<0.001)$ higher $\mathrm{Cr}(\mathrm{VI})$ removal than inactivated mycelia after incubation at $30^{\circ} \mathrm{C}$ for 72 hours. Incubation of cell - free extracts of both fungi with $\mathrm{NADH}$ at $30^{\circ} \mathrm{C}$ for 2 hours showed $\mathrm{Cr}(\mathrm{VI})$ reduction of $68.0 \%$ and $55.5 \%$ for $A$. niger and $A$. parasiticus, respectively. These findings suggest that uptake and metabolic reduction may be the process by which the two fungi are able to tolerate the toxic effects of hexavalent chromium. However, $\mathrm{Cr}$ removal via uptake by the two fungal biomass was observed to be in the range of $0.5-1.78 \%$ only, for all the concentrations applied, which is insignificant when compared with the initial $\mathrm{Cr}$ concentration in the culture medium. The results obtained through this investigation indicate the possibility of treating waste effluents containing hexavalent chromium using Aspergillus niger and $A$. parasiticus.
\end{abstract}

Keywords: Aspergillus spp; Cr(VI) Uptake/reduction; Bioremediation

\section{Introduction}

Chromium pollution is one of the most important environmental problems in many regions of the world. Improper disposal of this heavy metal at facilities in arid and semiarid regions has led to contaminations of underlying vadose zones and aquifers [1]. Hexavalent chromium, which is highly toxic to most biological systems is generated and released to the environment through a large number of industrial operations, including tanning, metal electroplating, iron and steel and inorganic chemical industries [2] and is largely responsible for the pollution of underground water due to its high mobility in soils.

Various solutions have been proposed for bioremediation of chromium contaminated soil and water with selected microbial species. Many species of bacteria [1,3-8], yeasts [9-11] and fungi [1216] have been investigated from this aspect, and the biosorption and bioaccumulation of chromium for bioremediation purposes have been demonstrated. Park et al. [13] had demonstrated that Pseudomonas putida culture was able to carry out enzymatic reduction of chromates. $\mathrm{Cr}(\mathrm{VI})$ was also shown to be quantitatively transformed to $\mathrm{Cr}$ (III) largely by soluble reductase activities in Bacillus species isolated from chromium-contaminated soil samples [5] Chromium reduction by the Bacillus species was not affected by sulphate and/or nitrate. The removal of chromium ions by the cyanobacterium, Anacystis nidulans immobilised on agar has been documented [3] Reports on chromate reduction by resting cells of sulphate-reducing bacteria particularly, Desulfovibrio vulgaris [17] and Cellulomonas sp. [4] are also available.
The biosorption processes for the removal of $\mathrm{Cr}(\mathrm{VI})$ from aqueous solutions and industrial effluents by dead fungal biomass [18] immobilized biomass of Rhizopus arrhizus [11,12] and fungal biomass of Rhizopus nigricans $[14,15]$ have been reported. Biosorption of chromium from aqueous solutions by fungal pellets of Aspergillus niger has also been reported [13]; The bioremediation of chromium by the yeast Pichia guilliermondii $[10]$ and Saccharomyces cerevisiae $[9,19]$ has also been studied. Increased tolerance to chromium and enhanced $\mathrm{Cr}$ accumulation capabilities were observed among $\mathrm{Cr}$-resistant mutants of Pichia guilliermondii obtained by means of environmental mutagenesis [10].

The mechanisms of chromium tolerance or resistance of selected microbes are of particular importance in both bioremediation and waste water treatment technologies. Studies of the various microbial uptake mechanisms for heavy metals could result in the identification of specific microbes with promising potential for application in metal

${ }^{*}$ Corresponding author: Shugaba A, Department of Biochemistry, University of Maiduguri, Maiduguri, Nigeria, E-mail: aliyushugaba@yahoo.co.uk, shugaba@ hotmail.com

Received February 15, 2012; Accepted April 11, 2012; Published April 13, 2012

Citation: Shugaba A, Buba F, Kolo BG, Nok AJ, Ameh DA, et al. (2012) Uptake and Reduction of Hexavalent Chromium by Aspergillus niger and Aspergillus parasiticus. J Pet Environ Biotechnol 3:119. doi:10.4172/2157-7463.1000119

Copyright: (C) 2012 Shugaba A, et al. This is an open-access article distributed under the terms of the Creative Commons Attribution License, which permits unrestricted use, distribution, and reproduction in any medium, provided the original author and source are credited. 
bioremediation. Prasenjit and Sumathi [16] had demonstrated the ability of Aspergillus foetidus to take up chromium during the stationary phase of growth and under non-supportive growth conditions. In this work we report the uptake and metabolic transformation of hexavalent chromium by cultures of Aspergillus niger and Aspergillus parasiticus.

\section{Materials and Methods}

\section{Fungal isolates}

The fungi, Aspergillus niger and Aspergillus parasiticus, used in this study were isolated from landfill and sludge samples obtained from the Neital Shoe Factory and Tannery, Maiduguri, Nigeria. The isolation and identification of the fungi was carried out in the Mycology laboratory of the Plant Pathology Unit of the Department of Crop Science, University of Maiduguri. The fungi were identified by their colony characteristics as well as their vegetative and reproductive structures as observed under the electron microscope. Some macroscopic characteristics used for the identification include, colour of the colony, patterns of growth of colony and the byproducts released by the organisms. Some of the microscopic characteristic as viewed under the microscope include, the shape of the conidia head, pattern of arrangement of spores on the conidia, shape of the spores and shape of the conidiophores. The isolates were further confirmed in the Department of Microbiology, Ahmadu Bello University, Zaria, Nigeria. The organisms were isolated and maintained on Sabouraud Dextrose Agar, SDA (Lab M, Biotech, England) at $\mathrm{pH}$ 5. Inoculated slants were incubated for 7 days at $30^{\circ} \mathrm{C}$ and then stored at $4^{\circ} \mathrm{C}$ until used.

\section{Growth medium and culture conditions}

For the growth of the fungi in suspension culture, a stock solution containing 0 to $20 \mathrm{mg} / \mathrm{l} \mathrm{Cr}(\mathrm{VI})$ was prepared by dissolving analytical grade potassium dichromate $\left(\mathrm{K}_{2} \mathrm{Cr}_{2} \mathrm{O}_{7}\right)$ in 1 litre of sterile modified Vogel's mineral salts medium [20-23]. The solution was adjusted to a final $\mathrm{pH}$ of $4.5 \pm 0.5$ and $100 \mathrm{ml}$ was used as culture medium for the growth of fungi. Spores of the two fungi were harvested from the 7day-old culture slants by washing with $0.2 \%$ Tween- 80 . After vigorous shaking, inocula containing an average of $5.00 \times 10^{3}$ spores per ml were obtained for each of the two fungal strains.

A batch system of cultivation in batch reactors using $150-\mathrm{ml}$ Erlenmeyer flasks on a rotary shaker (200 to $300 \mathrm{rpm}$ ) at pH 4 to 5 and temperature of $30^{\circ} \mathrm{C}$ for 96 hours was used for growing the fungi. The culture media in the bioreactor were inoculated with an average biomass of $50 \mathrm{mg}$ per liter of inoculum of the fungal strains. Culture media without chromium treatment, $0 \mathrm{mg} / \mathrm{l} \mathrm{Cr}(\mathrm{VI})$, served as control for the growth experiment.

\section{Determination of $\mathrm{Cr}(\mathrm{VI})$ removal in the fungal culture}

The removal of chromate from the culture solutions was determined by estimating the residual $\mathrm{Cr}(\mathrm{VI})$ in the culture media after the 96 hour growth period as previously described by Shugaba et al. [21-23] $\mathrm{Cr}(\mathrm{VI})$ uptake and reduction during growth was followed by loss of the yellow to orange colour of the dichromate solution and by the quantitative decrease in $\mathrm{Cr}(\mathrm{VI})$ concentration in culture $[6,24,25]$ also, as part of the $\mathrm{Cr}(\mathrm{VI})$ reduction studies, the concentrations of trivalent chromium, [Cr(III)], and total chromium, $\mathrm{Cr}_{\mathrm{T}}$ were also determined in the culture medium [26] Samples of the spent culture solutions were filtered using a membrane filter before measuring the $\mathrm{Cr}(\mathrm{VI}), \mathrm{Cr}(\mathrm{III})$ and $\mathrm{Cr}_{\mathrm{T}}$ concentrations.
The role of metabolic activity in $\mathrm{Cr}(\mathrm{VI})$ removal by the two fungi was evaluated as described by Desjardin et al. [27]. Active and inactivated mycelia of $A$. niger and $A$. parasiticus were incubated in culture medium spiked with $50 \mathrm{mg} / \mathrm{l} \mathrm{Cr}$ (VI) under the same conditions for 72 hours. Inactivation of the mycelia was achieved by autoclaving at $121^{\circ} \mathrm{C}$ for 20 minutes. In order to determine the effects of carbon sources (electron donors) on chromium removal by the two fungi, glucose, acetate and tannic acid were applied separately as sole carbon and energy sources in fresh culture media containing $20 \mathrm{mg} / \mathrm{l} \mathrm{Cr}(\mathrm{VI})$.

\section{Determination of $\mathrm{Cr}(\mathrm{VI}), \mathrm{Cr}(\mathrm{III})$ and $\mathrm{Cr}_{\mathrm{T}}$ concentrations in culture medium}

The concentration of hexavalent chromium, $\mathrm{Cr}(\mathrm{VI})$, in the culture media was determined spectrophotometrically using 1 , 5 -diphenylcarbazide as complexing agent [24,28-30]. One milliliter $(1 \mathrm{ml})$ of $0.2 \% \mathrm{w} / \mathrm{v}$ of 1,5 -diphenylcarbazide solution (prepared in $95 \%$ ethanol and $1 \mathrm{ml}$ of $1 /{ }_{5} \mathrm{H}_{2} \mathrm{SO}_{4}$ ) was added to $1 \mathrm{ml}$ of the sample solution. The solution was allowed to stand for 10 minutes after which the absorbance of the purple-coloured solution was read at $540 \mathrm{~nm}$. $\mathrm{Cr}(\mathrm{VI})$ concentration was extrapolated from a standard curve prepared from standard solutions of potassium dichromate.

$\mathrm{Cr}(\mathrm{III})$ and $\mathrm{Cr}_{\mathrm{T}}$ were determined using atomic absorption spectrophotometer with Zeeman graphite furnacve as described by $\mathrm{Xu}$ et al. [31]. For $\mathrm{Cr}$ (III) determination, about $20 \mathrm{ml}$ of the filtered medium was passed through anion exchange resin at a flow-rate of $1.0 \mathrm{ml} / \mathrm{min}$, and then it was collected for the determination of trivalent chromium, $\mathrm{Cr}$ (III), concentration by Atomic Absorption Spectrophotometer (AAS).

\section{Determination of total chromium uptake by fungal biomass}

For the determination of total chromium uptake by the fungi, the mycelia were acid digested $[10,32]$. The cells were separated from the culture media by filtration, washed with water and dried. The dry cells were weighed and then suspended in a known volume of concentrated nitric acid, kept for $30 \mathrm{~min}$ at room temperature, and heated gently on a heating mantle (at $60^{\circ} \mathrm{C}$ for $30 \mathrm{~min}$ ). After cooling to room temperature, hydrogen peroxide $\left(\mathrm{H}_{2} \mathrm{O}_{2}\right)$ solution was added (in a ratio of $7: 3 \mathrm{v} / \mathrm{v}$ nitric acid $/ \mathrm{H}_{2} \mathrm{O}_{2}$ ) and the samples were heated again for 15 minutes and then centrifuged at $1500 \mathrm{x} \mathrm{g}$. The supernatant was then used to determine the total chromium $\mathrm{Cr}_{\mathrm{T}}$ concentration using Atomic Absorption Spectrophotometer, AAS (Perkin Elmer, Japan Co, Ltd.) with Zeeman graphite furnace.

\section{Determination of $\mathrm{Cr}(\mathrm{VI})$ reducing activity of cell-free extracts of fungal mycelia}

The ability of the two fungi to reduce hexavalent chromium in solution was studied using cell - free extracts of exponentially grown mycelia. The cell-free extracts were prepared by homogenizing the mycelia in $10 \mathrm{ml}$ of $50 \mathrm{mM}$ Tris-HClbuffer ( $\mathrm{pH} 7.0$ ) and then centrifuged at $3000 \mathrm{x} \mathrm{g}$. The supernatant was then tested for ability to reduce $\mathrm{Cr}$ (VI). The $\mathrm{Cr}(\mathrm{VI})$ reducing activity was determined by measuring the decrease in $\mathrm{Cr}(\mathrm{VI})$ concentration [24] after incubation for 2 hours. The activity was assayed at $30^{\circ} \mathrm{C}$ in a reaction mixture containing $0.1 \mathrm{mM}$ NADH $(40 \mu \mathrm{l}), 50 \mathrm{mM}$ Tris - $\mathrm{HCl}$ buffer of pH $7.0(1.8 \mathrm{ml}) 0.05 \mathrm{mM}$ $\mathrm{K}_{2} \mathrm{Cr}_{2} \mathrm{O}_{7}(100 \mu \mathrm{l})$ and $600 \mu \mathrm{l}$ of $0.2 \% 1,5$ - diphenylcarbazide reagent and the absorbance was read at $540 \mathrm{~nm}$ against a reference sample incubated without the extract.

\section{Measurement of fungal biomass concentration}

The biomass concentration in the culture media was measured 
by collecting the biomass on pre-dried Whatman No. 1 filter paper, washing the biomass with distilled water and drying to constant weight at $70^{\circ} \mathrm{C}[20]$. The biomass concentration was calculated as follows:

Biomass concentration $(\mathrm{mg} / \mathrm{l})=\frac{A-B}{V}$

Where $\mathrm{A}=$ weight of the dry cells + filter paper

$\mathrm{B}=$ weight of the filter paper, and

$\mathrm{V}=$ Volume of culture media (l)

\section{Measurement of specific growth rate}

Culture turbidity was used to determine the specific growth rates $(\mu)$ of fungal cultures growing in shake - flask batch cultures [33]. Erlenmeyer flasks containing $100 \mathrm{ml}$ of the growth medium and $\mathrm{Cr}(\mathrm{VI})$ at concentrations of $5-20 \mathrm{mg} / \mathrm{l}$ were inoculated with $2 \mathrm{ml}$ of exponential - phase culture grown in identical medium (initial cultures absorbance of $0.1-0.4 \mathrm{~nm}$ ). The fungal cultures were then incubated at $30^{\circ} \mathrm{C}$ on a rotary shaker at $200 \mathrm{rpm}$ and changes in turbidity were determined at 24 hours interval for five days. Culture turbidity was measured spectrophotometrically by taking the absorbance of the growing cultures at $560 \mathrm{~nm}$. The specific growth rate, $\mu\left(\mathrm{hr}^{-1}\right)$ was determined by dividing the change in turbidity by the time interval within which growth was assessed.

\section{Statistics}

The data obtained in the study were analyzed by one-way analysis of variance, (ANOVA) and the Student t-test (using GraphPad Instat statistical program). Differences between means were considered significant at values of $\mathrm{P}<0.05$.

\section{Results and Discussion}

\section{Changes in $\mathrm{Cr}$ (VI) concentration during fungal growth}

Figure 1 shows the changes in hexavalent chromium concentrations during growth of $A$. niger and $A$. parasiticus. $\mathrm{Cr}(\mathrm{VI})$ was significantly $(\mathrm{P}<0.001)$ reduced in both cultures every 24 hours with decolouration of the characteristic pale yellow colour of the dichromate. At 96 hours, the solution became completely colourless, and exhibited a $\mathrm{Cr}(\mathrm{VI})$ concentration of only $0.74 \pm 0.55$ and $1.69 \pm 0.29 \mathrm{mg} / \mathrm{l}$ in $A$. niger and A. parasiticus cultures, respectively. Thus, with the initial dichromate concentration of $20 \mathrm{mg} / \mathrm{l}$ up to $96.3 \%$ and $91.6 \% \mathrm{Cr}(\mathrm{VI})$ removal was achieved within 96 hours by $A$. niger and $A$. parasiticus, respectively. The significant reduction in media $\mathrm{Cr}(\mathrm{VI})$ concentration following fungal growth in both cultures suggest that $A$. niger and $A$. parasiticus are

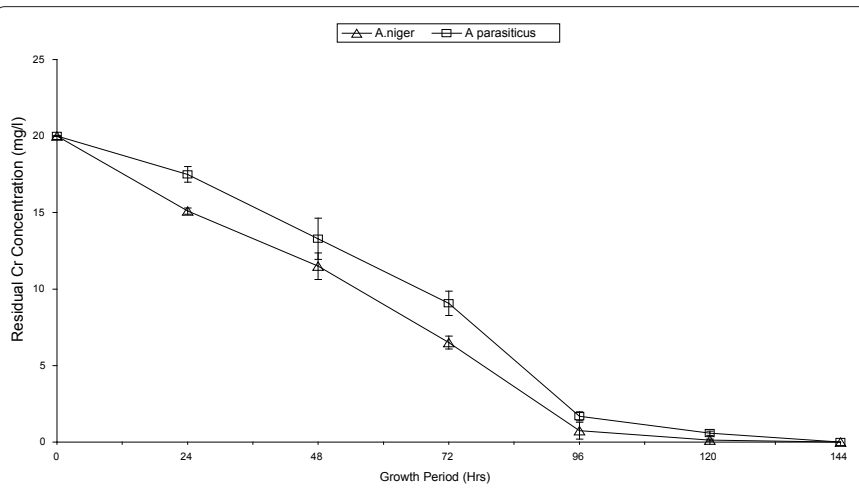

Figure 1: Changes in $\mathrm{Cr}(\mathrm{VI})$ concentration during fungal growth in culture solutions treated with hexavalent chromium at initial concentration of $20 \mathrm{mg} / \mathrm{l}$. both capable of removing this toxic metal in solutions. A. niger culture showed significantly $(\mathrm{P}<0.01)$ lower $\mathrm{Cr}(\mathrm{VI})$ concentration compared to that of $A$. parasiticus within 72 hours of growth, suggesting that it is more efficient than A. parasiticus. However, both organisms showed complete removal of $\mathrm{Cr}(\mathrm{VI})$ from their media by 144 hours of growth. The rate of $\mathrm{Cr}(\mathrm{VI})$ removal was $0.21 \pm 0.09 \mathrm{mgl}^{-1} \mathrm{hr}^{-1}$ and $0.20 \pm 0.07$ $\mathrm{mgl}^{-1} \mathrm{hr}^{-1}$ for $A$. niger and A. parasiticus, respectively.

Chromium removal using bacterial chromate reductase has been reported by several workers $[5,6,25,29$,$] . The complete decolouration$ and clearance of up to $20 \mathrm{mg} / \mathrm{l} \mathrm{Cr}(\mathrm{VI})$ from the culture media of $A$. niger and $A$. parasiticus suggests that these organisms may have the enzymic capabilities for converting $\mathrm{Cr}(\mathrm{VI})$ to $\mathrm{Cr}(\mathrm{III})$, thus indicating their ability for adaptation. The observed decrease in $\mathrm{Cr}(\mathrm{VI})$ concentration in culture media of $A$. niger and $A$. parasiticus may be related to a metabolic reduction of $\mathrm{Cr}(\mathrm{VI})$ ions, a metabolic uptake of $\mathrm{Cr}(\mathrm{VI})$ with no reduction, or a passive uptake of $\mathrm{Cr}(\mathrm{VI})$ with no reduction (i.e. biosorption). Metabolic uptake with reduction [27,25,29,34] as well as active uptake without reduction (bioaccumulation) and passive uptake (biosorption) of metal ions, including hexavalent chromium [27,35,36] are known processes of bioremediation by microorganisms.

The cellular concentration of $\mathrm{Cr}(\mathrm{VI})$ in the two fungi (Figure 2) increased significantly $(\mathrm{P}<0.05-0.001)$ with increasing concentration of $\mathrm{Cr}(\mathrm{VI})$ treatment; suggesting that the two organisms take up chromium ions from the media solution. Biosorption and bioaccumulation are processes by which microorganisms remove metal ions from solutions and industrial effluents [11,35-37]. Aspergillus mycelia have particularly been found to be efficient for removing zinc and thorium from solutions and polluted water [38,39]. In this study A. parasiticus had significantly $(\mathrm{P}<0.001)$ higher cellular $\mathrm{Cr}(\mathrm{VI})$ concentration $(587.56 \pm 47.17 \mu \mathrm{g} / \mathrm{g})$ compared to A. niger $(82.12 \pm 3.45 \mu \mathrm{g} / \mathrm{g})$ at the highest $\mathrm{Cr}(\mathrm{VI})$ treatment $(20 \mathrm{mg} / \mathrm{l})$. Thus $A$. parasiticus accumulates more chromium than A. niger.

Accumulation of high concentrations of $\mathrm{Cr}(\mathrm{VI})$ up to $34 \mathrm{mg} / \mathrm{g}$ dry weight by some microorganisms has been reported [40]. The mechanism of $\mathrm{Cr}(\mathrm{VI})$ - resistance and reduction may differ in microbial community from group to group or from strain to strain within a group [41] In some organisms $\mathrm{Cr}(\mathrm{VI})$ reduction takes place intracellularly because the enzyme is membrane-bound, and in such cases the substrate is taken up from the medium into the cells [34]. The rate of $\mathrm{Cr}(\mathrm{VI})$ uptake and its subsequent conversion to $\mathrm{Cr}(\mathrm{III})$ differ from organism to organism and reduced substrate uptake is said to be one of the mechanisms of chromium resistance in many microorganisms $[42,43]$.

The significant difference in intracellular $\mathrm{Cr}(\mathrm{VI})$ concentration between $A$. niger and A. parasiticus may therefore be due to differences in the rate of chromium uptake between the two organisms and/or rate of conversion to $\mathrm{Cr}(\mathrm{III})$. It is likely that $A$. parasiticus may have taken up so much $\mathrm{Cr}(\mathrm{VI})$ that it could not convert to $\mathrm{Cr}(\mathrm{III})$ since intracellular accumulation of $\mathrm{Cr}(\mathrm{VI})$ may also disturb the normal functioning of microbial cells [34]. In studies of chromium toxicity and accumulation, Kshminska et al. [10] reported diverse, individual and complex mechanism of chromium bioremediation in the cells of different strains of the yeast Pichia guilliermondii. They observed that all the investigated strains responded to $\mathrm{Cr}(\mathrm{VI})$ treatment with substantial changes in protein profile patterns, which included both induction and suppression of certain polypeptides. In particular they 
observed the induction of a $62 \mathrm{kDa}$ as well as the suppression of a 59 $\mathrm{kDa}$ proteins upon $\mathrm{Cr}(\mathrm{VI})$ treatment and suggested that these proteins are involved in $\mathrm{Cr}(\mathrm{VI})$ bioremediation by $P$. guilliermondii.

\section{Influence of carbon source on $\mathrm{Cr}(\mathrm{VI})$ reduction}

The effect of carbon source on chromium reduction in cultures of A. niger and A. parasiticus is shown in Figure 3. Throughout the growth period, $\mathrm{Cr}(\mathrm{VI})$ concentrations were lower in cultures containing glucose compared to those with acetate and tannin as carbon sources; the difference being significant $(\mathrm{P}<0.001)$ between 72 and 120 hours. Cultures containing acetate also showed significantly $(\mathrm{P}<0.01)$ lower $\mathrm{Cr}(\mathrm{VI})$ compared to those with tannic acid as carbon and energy source (electron donor). This finding suggests that glucose and acetate as carbon and energy source support $\mathrm{Cr}(\mathrm{VI})$ reduction better than the tannin Figure 4. Glucose and acetate are known electron donors for $\mathrm{Cr}(\mathrm{VI})$ reduction by several organisms; indeed, about $2700 \mathrm{mg} / \mathrm{l}$ glucose was utilized to reduce $\mathrm{Cr}(\mathrm{VI})$ from $20 \mathrm{mg} / \mathrm{l}$ to $12 \mathrm{mg} / \mathrm{l}$ in 24 hours, and that $\mathrm{Cr}(\mathrm{VI})$ reduction ceased when glucose was nearly depleted within the 24 hours growth period [44]. According to Prasenjit and Sumathi [16], the initial rate of chromium uptake is enhanced by higher biomass concentrations and the presence of glucose. In an earlier study, it was shown that $\mathrm{Cr}(\mathrm{VI})$ reduction by pure culture of $S$. thermocarboxydus NH50 was more rapid with glycerol as sole carbon source than with glucose [27].

However, the fact that $\mathrm{Cr}(\mathrm{VI})$ concentration was significantly $(\mathrm{P}<0.001)$ reduced by about $85.0 \%$ (A. niger) and $68.8 \%$ (A. parasiticus)

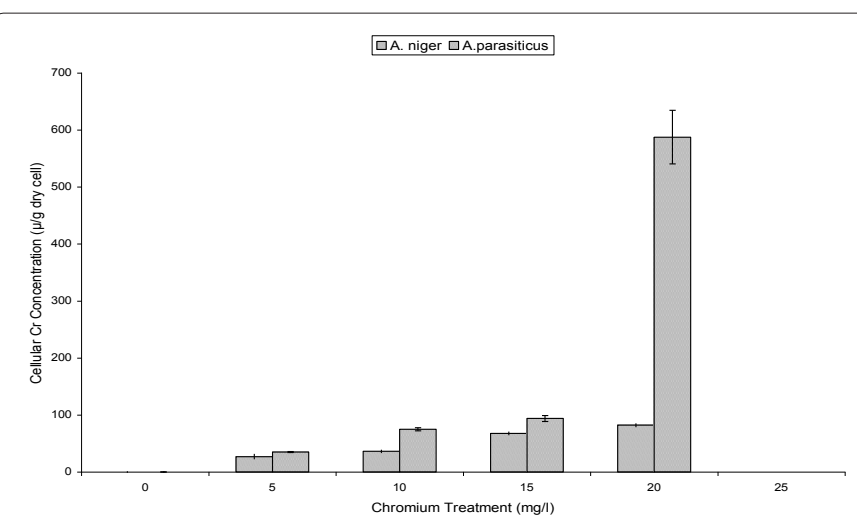

Figure 2: Cellular $\mathrm{Cr}(\mathrm{VI})$ concentration at 96 hours of growth

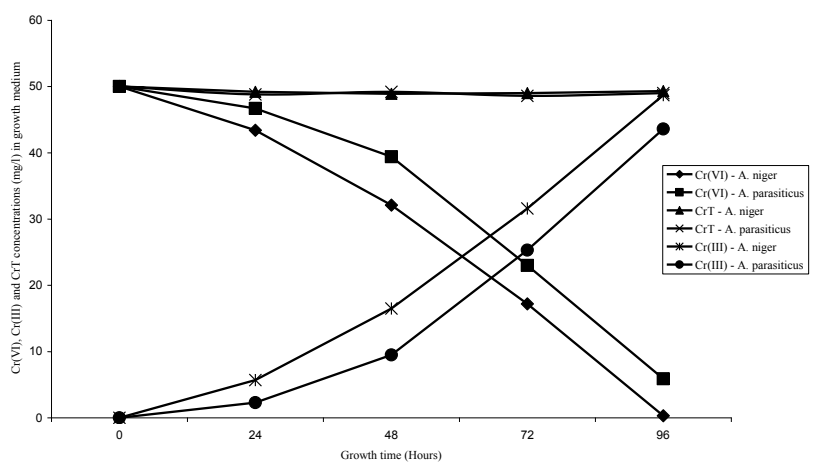

Figure 3: Concentrations (mg/l) of $\mathrm{Cr}(\mathrm{VI}), \mathrm{Cr}(\mathrm{III})$ and total chromium $(\mathrm{CrT})$ in culture medium during fungal growth for 96 hours.

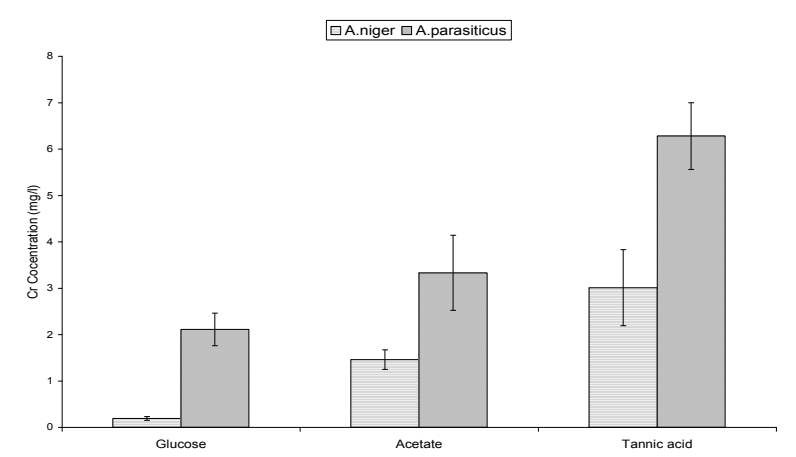

Figure 4: Influence of carbon source on $\mathrm{Cr}(\mathrm{VI})$ removal from culture solution by the fungi.

\begin{tabular}{|c|c|c|c|c|}
\hline & \multicolumn{2}{|c|}{ A. niger } & \multicolumn{2}{c|}{ A. parasiticus } \\
\hline No cells & Active & Inactive & Active & Inactive \\
\hline & & & & \\
$49.27 \pm 0.24$ & $\begin{array}{c}16.72 \pm 1.25 \\
(66.1 \%)\end{array}$ & $\begin{array}{c}40.44 \pm 0.97 \\
(17.9 \%)\end{array}$ & $\begin{array}{c}22.83 \pm 1.03 \\
(53.7 \%)\end{array}$ & $\begin{array}{c}41.30 \pm 1.13 \\
(16.2 \%)\end{array}$ \\
\hline
\end{tabular}

Values are presented as Means $\pm S$. D of triplicate determinations. Mean values are statistically different $(P<0.05)$

Figures in parentheses represent percentage $\mathrm{Cr}(\mathrm{VI})$ removal

Table 1: Residual concentration of $\mathrm{Cr}(\mathrm{VI})(\mathrm{mg} / \mathrm{l})$ in solution after 72 hours of incubation at $30^{\circ} \mathrm{C}$ in Vogel's mineral salt medium spiked with $\mathrm{Cr}(\mathrm{VI})$ at initial concentration of $50 \mathrm{mg} / \mathrm{l}$.

after 96 hours of growth in media with tannic acid as sole carbon and energy source shows that these fungi are capable of utilizing tannins as carbon source or electron donors for $\mathrm{Cr}(\mathrm{VI})$ removal in solutions. The tannic acid, being a complex polyphenol, may not be readily available for use by the organisms; it may therefore have to be degraded to simpler, less toxic products, before it can be used to fuel $\mathrm{Cr}(\mathrm{VI})$ reduction. Indeed, it was reported that microorganisms breakdown complex tannins to simpler and less toxic products, which they could use as nutrients for growth $[45,46]$ The growth of Fusarium flocciferum [47] the Penicillium strain $\mathrm{Bi} 7 / 2$ [46], Lactobacillus hilgardii and Lactobacillus plantarum $[46,48]$ on tannins such as protocatechuic, gallic, ferullic and syringic acids has been described. These organisms were able to grow on the tannins after degrading them into smaller less toxic products, which they used as source of energy and carbon for growth and metabolism.

\section{$\mathrm{Cr}(\mathrm{VI})$ removal by active and inactive fungal biomass}

The results presented in Table 1 show that in the media with active mycelia, $A$. niger culture had significantly $(\mathrm{P}<0.05)$ lower $\mathrm{Cr}(\mathrm{VI})$ concentrations $(16.72 \pm 1.25 \mathrm{mg} / \mathrm{l})$ compared to the active $A$. parasiticus culture $(22.83 \pm 1.03 \mathrm{mg} / \mathrm{l})$; representing $66.6 \%$ and $54.3 \%$ $\mathrm{Cr}(\mathrm{VI})$ removal, respectively. However, there were no significant $(\mathrm{P}>0.05)$ differences in residual $\mathrm{Cr}(\mathrm{VI})$ concentrations in the media containing the inactivated mycelia of these fungi. For both organisms, the media with active cells had significantly $(\mathrm{P}<0.001)$ lower $\mathrm{Cr}(\mathrm{VI})$ concentrations after the 72 hours of incubation compared to those with inactivated mycelia. Also, for both fungi, the residual $\mathrm{Cr}(\mathrm{VI})$ concentrations were significantly lower in media with the active mycelia $(\mathrm{P}<0.001)$ and inactivated mycelia $(\mathrm{P}<0.05)$ compared to media incubated without the mycelia. In the media incubated with the inactivated mycelia, the $\mathrm{Cr}(\mathrm{VI})$ removal was $19.1 \%$ and $15.7 \%$ for $A$. 
Citation: Shugaba A, Buba F, Kolo BG, Nok AJ, Ameh DA, et al. (2012) Uptake and Reduction of Hexavalent Chromium by Aspergillus niger and Aspergillus parasiticus. J Pet Environ Biotechnol 3:119. doi:10.4172/2157-7463.1000119

niger and A.parasiticus, respectively. There was no significant decrease in $\mathrm{Cr}(\mathrm{VI})$ concentration in the absence of the mycelia.

These observations suggest that $\mathrm{Cr}(\mathrm{VI})$ removal by $A$. niger and $A$. parasiticus is mainly a metabolic process involving either a metabolic uptake and reduction or metabolic uptake with no reduction (i.e. bioaccumulation). In addition, the significant decrease in $\mathrm{Cr}(\mathrm{VI})$ concentration in the presence of inactivated mycelia compared to values obtained in the absence of mycelia suggests that a passive uptake (biosorption) may also be involved in the removal process for $\mathrm{Cr}(\mathrm{VI})$. Bioaccumulation is a growth dependent process by which microbial cells sequester metals ions intracellularly by an active metabolic process; it is therefore mediated only by the living biomass [27,35]. In biosorption, the microbial biomass binds substantial amounts of metal ions by a passive process mediated by living and non - living biomass [27,35-37].

The mechanisms of biosorption mainly involve cell surface complexation, ion-exchange, chelation, and microprecipitation [49]. A large number of microorganisms are known to bind a variety of heavy metals with varying degrees of affinity. However, fungal biomasses exhibit a high percentage of cell wall material, with excellent metal binding properties [37,49]. Among the fungi that have shown excellent potential of metal biosorption, Aspergillus and Rhizopus species have been well studied [13-15,37,50].

\section{$\mathrm{Cr}(\mathrm{VI})$ - reducing activity of fungal extracts}

The residual $\mathrm{Cr}(\mathrm{VI})$ concentrations of the reaction mixture incubated with the cell-free extracts of both organisms decreased significantly $(\mathrm{P}<0.001)$ within 2 hours, from an initial concentration of $7.35 \pm 0.05 \mathrm{mg} / \mathrm{l}$ to $2.35 \pm 0.17 \mathrm{mg} / \mathrm{l}$ and $3.27 \pm 0.07 \mathrm{mg} / \mathrm{l}$ for $A$. niger and $A$. parasiticus, respectively. This shows $\mathrm{Cr}(\mathrm{VI})$ reduction of 68.0 and $55.5 \%$ for $A$. niger and $A$. Parasiticus, respectively. The observation of $\mathrm{Cr}(\mathrm{VI})$ reduction by the cell-free extracts of the two fungi suggests that metabolic uptake and reduction to $\mathrm{Cr}$ (III) may be the process by which these organisms carry out bioremediation of $\mathrm{Cr}(\mathrm{VI})$ in solutions. The conversion of $\mathrm{Cr}(\mathrm{VI})$ to $\mathrm{Cr}$ (III) has been recognized as one of the several mechanisms by which $\mathrm{Cr}(\mathrm{VI})$-resistant organisms tolerate the toxic effects of chromium $[25,29,34]$. Cr(VI) - resistant organisms are known to produce chromium reductase, which mediates the transfer of electrons from $\mathrm{NAD}(\mathrm{P}) \mathrm{H}$ to $\mathrm{Cr}(\mathrm{VI})$, converting it to $\mathrm{Cr}(\mathrm{III})[25,29,51]$. The abilities of Aspergillus and Penicillium species to massively reduce $\mathrm{Cr}(\mathrm{VI})$ to $\mathrm{Cr}(\mathrm{III})$ have earlier been reported [26,52-55].

\section{Chromium removal via uptake by the fungal biomass}

In Table 2 are results showing Cr uptake determined by multiplying the concentration of $\mathrm{Cr}$ in the fungal cells grown for 96 hours at $30^{\circ} \mathrm{C}$ by the fungal biomass concentration. $\mathrm{Cr}$ accumulation by the two organisms ranged from $0.5-1.78 \%$, for all the concentrations applied; the percentage $\mathrm{Cr}$ uptake decreases with increasing concentrations of $\mathrm{Cr}(\mathrm{VI})$ treatment in the growth medium. These chromium uptake values are insignificant when compared with the initial $\mathrm{Cr}$ concentration in the culture medium. Similar observations on $\mathrm{Cr}$ uptake by fungal biomass of Aspergillus (strain Ed8) and Penicillium (strain H13) were reported by Acevedo-Aguilar et al. [26] leading to suggestion that $\mathrm{Cr}$ uptake by these fungal strains was almost negligible, as compared to the total $\mathrm{Cr}$ present in the growth medium. They reported a total $\mathrm{Cr}$ uptake of only about $0.06 \%$ and $0.04 \%$ by the fungal biomass of the Aspergillus sp. (strain Ed8) and the Penicillium sp. (strain H13), respectively after a growth period of 96 hours in a medium containing initial $\mathrm{Cr}$ content of $2500 \mu \mathrm{g}$. Thus, very little of the $\mathrm{Cr}$ in the culture medium was incorporated into the biomass, indicating that the decrease of $\mathrm{Cr}(\mathrm{VI})$ in the culture media of strains Ed8 and $\mathrm{H} 13$ resulted from its quantitative reduction to $\mathrm{Cr}(\mathrm{III})$ rather than from its uptake by the biomass.

In an earlier study, however, Park et al. [52] reported that when synthetic wastewater containing $\mathrm{Cr}(\mathrm{VI})$ was placed in contact with

\begin{tabular}{|c|c|c|c|c|c|c|c|c|}
\hline \multirow{2}{*}{$\begin{array}{c}\mathrm{Cr}(\mathrm{VI}) \\
\text { Treatment } \\
(\mu \mathrm{g} / \mathrm{ml})\end{array}$} & \multicolumn{2}{|c|}{$\begin{array}{c}\text { Cr concentration } \\
\text { in mycelia ( } \mu \mathrm{g} / \mathrm{g} \text { dry biomass) }\end{array}$} & \multicolumn{2}{|c|}{$\begin{array}{c}\text { Mean Biomass } \\
\text { Concentration }(\mathrm{g} / \mathrm{ml})\end{array}$} & \multicolumn{2}{|c|}{$\begin{array}{l}\text { Amount of } \mathrm{Cr} \text { removed } \\
\text { by fungus }(\mu \mathrm{g})\end{array}$} & \multicolumn{2}{|c|}{$\% \mathrm{Cr}$ removed from medium } \\
\hline & A. niger & A. parasiticus & A. niger & A. parasiticus & A. niger & A. parasiticus & A. niger & A. parasiticus \\
\hline 5 & $26.93 \pm 4.75$ & $35.02 \pm 1.07$ & 0.0033 & 0.0024 & 0.089 & 0.084 & 1.78 & 1.68 \\
\hline 10 & $36.18 \pm 2.98$ & $75.07 \pm 2.79$ & 0.0025 & 0.0013 & 0.091 & 0.098 & 0.91 & 0.98 \\
\hline 15 & $67.57 \pm 3.81$ & $93.86 \pm 5.33$ & 0.0013 & 0.0010 & 0.088 & 0.094 & 0.57 & 0.63 \\
\hline 20 & $82.12 \pm 3.45$ & $587.57 \pm 47.17$ & 0.0012 & 0.0002 & 0.099 & 0.118 & 0.50 & 0.59 \\
\hline
\end{tabular}

Table 2: Chromium uptake by the biomass of the fungal strains after 96 hours of growth.

\begin{tabular}{|c|c|c|c|c|c|c|}
\hline \multirow{2}{*}{$\begin{array}{l}\text { Growth } \\
\text { Period } \\
\text { (Hours) }\end{array}$} & \multicolumn{3}{|c|}{ A. niger } & \multicolumn{3}{|c|}{ A. parasiticus } \\
\hline & $\mathrm{Cr}(\mathrm{VI})$ & $\mathrm{CrT}$ & $\mathrm{Cr}(\mathrm{III})$ & $\mathrm{Cr}(\mathrm{VI})$ & $\mathrm{CrT}$ & $\mathrm{Cr}(\mathrm{III})$ \\
\hline 0 & $50.0 \pm 0.12$ & $50 \pm 0.02$ & 0.0 & $50 \pm 0.10$ & $50 \pm 0.05$ & 0.0 \\
\hline 24 & $\mathrm{a} 43.4 \pm 1.03$ & $49.2 \pm 0.05$ & a $5.7 \pm 0.11$ & $\mathrm{a} 46.7 \pm 0.08$ & $48.8 \pm 0.19$ & a2.3 \pm 0.05 \\
\hline 48 & ${ }^{b} 32.1 \pm 0.22$ & $48.9 \pm 0.15$ & ${ }^{b} 16.5 \pm 0.07$ & ${ }^{b} 39.4 \pm 0.09$ & $49.2 \pm 0.31$ & $9.5 \pm 0.75$ \\
\hline 72 & c17.2 \pm 0.85 & $49.0 \pm 1.00$ & c31.6 \pm 0.45 & ${ }^{c} 23.0 \pm 0.61$ & $48.6 \pm 0.72$ & ${ }^{c} 25.3 \pm 1.01$ \\
\hline 96 & ${ }^{\mathrm{d}} 0.3 \pm 0.01$ & $49.3 \pm 0.97$ & $\mathrm{~d} 48.7 \pm 0.52$ & ${ }^{d} 5.9 \pm 0.06$ & $49.0 \pm 0.84$ & $\mathrm{~d} 43.6 \pm 0.88$ \\
\hline
\end{tabular}

Values are presented as Mean \pm S.D of triplicate determinations

Mean values with different superscripts along a column are statistically different $(P<0.05)$

Table 3: Concentrations (mg/l) of hexavalent chromium [ $\mathrm{Cr}(\mathrm{VI})]$, total chromium $(\mathrm{CrT})$ and trivalent chromium [ $\mathrm{Cr}(\mathrm{III})]$ in fungal cultures during the 96 hours growth period. 
Citation: Shugaba A, Buba F, Kolo BG, Nok AJ, Ameh DA, et al. (2012) Uptake and Reduction of Hexavalent Chromium by Aspergillus niger and Aspergillus parasiticus. J Pet Environ Biotechnol 3:119. doi:10.4172/2157-7463.1000119

Page 6 of 8

dead fungal biomass of Aspergillus niger, the $\mathrm{Cr}(\mathrm{VI})$ was completely removed from aqueous solution, whereas $\mathrm{Cr}$ (III), which was not initially present, appeared in aqueous solution Table 3. By using desorption and X-Ray Photoelectron Spectroscopy (XPS) studies they showed that most of the $\mathrm{Cr}$ bound onto the biomass was in the trivalent form and postulated that the main mechanism of $\mathrm{Cr}(\mathrm{VI})$ removal was a redox reaction between $\mathrm{Cr}(\mathrm{VI})$ and the dead fungal biomass, which is quite different from previously reported mechanisms. It was also reported that Trichoderma inhamatum, grown in a batch culture system, exhibited a remarkable capacity to tolerate and completely reduce $\mathrm{Cr}(\mathrm{VI})$ to $\mathrm{Cr}(\mathrm{III})$ from initial concentrations of 0.83 up to 2.43 $\mathrm{mM}[56]$ and that the specific and volumetric rates of $\mathrm{Cr}(\mathrm{VI})$ reduction by this fungus decreased as the initial $\mathrm{Cr}(\mathrm{VI})$ concentration increased.

It has been reported that in some chromate-resistant yeasts, the general mechanism of $\mathrm{Cr}(\mathrm{VI})$ resistance is related to limited ion uptake rather than to chemical reduction of toxic species of the metal ion . However, other yeasts such as Candida maltosa [57] showed some ability to reduce $\mathrm{Cr}(\mathrm{VI})$ and also the capability to accumulate chromium in the biomass. Prasenjit and Sumathi [16] had reported 97\% decrease in hexavalent chromium (initial concentration, $5 \mu \mathrm{g} / \mathrm{g}$ ) at the end of 92 hours of growth in Aspergillus foetidus culture, possibly due to its reduction to $\mathrm{Cr}$ (III) and/or complexation with organic compounds released due the metabolic activity of the fungus. Thus, variations in metal tolerance may be due to the presence of different types of tolerance processes or resistance mechanisms exhibited by different isolates. Sun and Shao [58] had demonstrated that both intracellular bioaccumulation and extracellular biosorption contributed to the high resistance of Penicillium sp. Psf-2 to lead. Sintuprapa et al. [59] also suggested that ion exchange and intracellular accumulation in the form of polyphosphate precipitation are the mechanisms of $\mathrm{Zn}^{2+}$ uptake by living cells of Penicillium sp. The resistance of the bacterium Ralstonia mettalidurans $\mathrm{CH} 34$ to $\mathrm{Pb}$ is mediated by a P-type ATPase, which can transport lead out of the cell. Copper resistance in Aspergillus niger is due to an active process involving copper metallothionein synthesis [60].

Among microorganisms, fungal biomass offers the advantage of having a high percentage of cell wall material with excellent metalbinding properties [35-37]. Many fungi and yeast, particularly the genera Rhizopus, Aspergillus, Streptoverticillum and Saccharomyces have shown excellent potential for metal biosorption and bioaccumulation. The entry of all metal ions into the plasma membrane and cytoplasm takes place via the cell wall, which consists of a variety of polysaccharides and proteins that offer a number of active sites for metal binding. Differences in the cell wall composition among different species of microorganisms and the intra species differences can thus cause significant differences in the type and amount of metal binding to them. Fungi generally show greater resistance to heavy metals than many bacterial species [61] because mycelial growth gives the organism a larger surface area, which provides greater protection to sensitive organelles of the fungi. In addition, fungi are eukaryotic cells, which contain more genes that provide other means of dealing with inhibitory compounds such as toxic metals.

\section{Regeneration of fungal cells after initial exposure to $\mathrm{Cr}(\mathrm{VI})$}

Tables 4 and 5 show the specific growth rates and biomass concentrations, respectively, for both fungi after sub-culturing from the $\mathrm{Cr}(\mathrm{VI})$ treated cultures into non-chromium media. The specific growth rates for both organisms sub-cultured from all the treatments were not significantly $(\mathrm{P}>0.05)$ different. Similarly, the biomass concentrations of both organisms were not significantly $(\mathrm{P}>0.05)$ different, except for those of $A$. parasiticus sub-cultured from the $20 \mathrm{mg} \mathrm{Cr}(\mathrm{VI}) / 1$ treatment which showed significantly $(\mathrm{P}<0.05)$ lower biomass compared to the rest.

Biotechnological exploitation of microbial biosorption and bioaccumulation technology for removal of heavy metals from wastewater and industrial effluents depends on the efficiency of the

\begin{tabular}{|c|c|c|}
\hline \multirow{2}{*}{\begin{tabular}{|c|}
$|c|$ \\
\multirow{2}{*}{ Cr(VI) Treatment }
\end{tabular}} & Aspergillus niger & Specific growth rate, $\mu \mathrm{hr}^{-1}$ \\
\cline { 2 - 3 } $\begin{array}{c}\text { Control } \\
0 \mathrm{mg} / \mathrm{l}\end{array}$ & $0.27 \pm 0.02$ & $0.21 \pm 0.06$ \\
\hline $5 \mathrm{mg} / \mathrm{l}$ & $0.29 \pm 0.04$ & $0.18 \pm 0.01$ \\
\hline $10 \mathrm{mg} / \mathrm{l}$ & $0.25 \pm 0.02$ & $0.22 \pm 0.03$ \\
\hline $15 \mathrm{mg} / \mathrm{l}$ & $0.24 \pm 0.01$ & $0.18 \pm 0.06$ \\
\hline $20 \mathrm{mg} / \mathrm{l}$ & $0.25 \pm 0.05$ & $0.17 \pm 0.02$ \\
\hline
\end{tabular}

Values are mean \pm S.D. of four determinations $(P>0.05)$

Table 4: Specific growth rate, $\mu\left(\mathrm{hr}^{-1}\right)$ of $A$. niger and $A$. parasiticus regenerated from hexavalent chromium treated cultures into chromium-free medium.

\begin{tabular}{|c|c|c|c|c|}
\hline \multirow{2}{*}{$\begin{array}{c}\mathrm{Cr}(\mathrm{VI}) \\
\text { Treatment } \\
\quad(\mathrm{mg} / \mathrm{l})\end{array}$} & \multicolumn{2}{|c|}{ Biomass concentration $(\mathrm{g} / \mathrm{l})$ in $\mathrm{Cr}(\mathrm{VI})$ treated cultures } & \multicolumn{2}{|c|}{$\begin{array}{l}\text { Biomass concentration }(\mathrm{g} / \mathrm{l}) \text { in } \mathrm{Cr}(\mathrm{VI}) \text {-free medium after initial } \\
\text { exposure to } \mathrm{Cr}(\mathrm{VI})\end{array}$} \\
\hline & A. niger & A. parasiticus & A. niger & A. parasiticus \\
\hline 0 & a3.344 \pm 0.010 & a $2.982 \pm 0.013$ & a3.311 \pm 0.050 & a2.926 \pm 0.024 \\
\hline 5 & a3.332 \pm 0.030 & a2.352 \pm 0.017 & a3.246 \pm 0.048 & a2.900 \pm 0.037 \\
\hline 10 & ${ }^{\mathrm{b}} 2.520 \pm 0.023$ & b1.303 \pm 0.034 & a3.331 \pm 0.025 & a2.856 \pm 0.028 \\
\hline 15 & $c 1.330 \pm 0.018$ & $\mathrm{~b} 1.000 \pm 0.016$ & a $3.229 \pm 0.031$ & a2.853 \pm 0.045 \\
\hline 20 & ${ }^{c} 1.200 \pm 0.015$ & ${ }^{c} 0.180 \pm 0.015$ & a $3.297 \pm 0.023$ & b2.740 \pm 0.023 \\
\hline
\end{tabular}

Values are presented as Mean \pm S.D. of four determinations.

Mean values with different superscripts along a column are significantly different $(P<0.05)$.

Table 5: Biomass concentrations of $A$. niger and $A$. parasiticus regenerated from hexavalent chromium treated cultures in a chromium-free medium. 
Citation: Shugaba A, Buba F, Kolo BG, Nok AJ, Ameh DA, et al. (2012) Uptake and Reduction of Hexavalent Chromium by Aspergillus niger and Aspergillus parasiticus. J Pet Environ Biotechnol 3:119. doi:10.4172/2157-7463.1000119

Page 7 of 8

regeneration of the microbial biomass for reuse in multiple cycles [35]. In bioremediation of metal ions, the performance of living microbial biomass depends much on cell age and toxic effects of heavy metals may result in cell death [36]. Hexavalent chromium is highly toxic to a lot of microorganisms, and like other heavy metal ions such as $\mathrm{Cu}(\mathrm{II}), \mathrm{Pb}(\mathrm{II}), \mathrm{Zn}(\mathrm{II})$, etc. it may cause structural damage in cells and consequently a permanent effect on cell growth $[34,62]$.

The results obtained in this study show that although A.niger and $A$. parasiticus were exposed to concentrations of $\mathrm{Cr}(\mathrm{VI})$, which severely inhibited their growth; these organisms were capable of regenerating with specific growth rates $(\mu)$ and biomass comparable to those of the chromium-free control organisms. This observation suggests a remarkable potential for application of these fungi in chromium biotreatment. Sani et al. [62] had reported similar observation with Desulfovibrio desulfuricans where toxic concentration of the heavy metal ions, $\mathrm{Cu}(\mathrm{II}), \mathrm{Pb}(\mathrm{II})$ and $\mathrm{Zn}(\mathrm{II})$ utterly inhibited growth, but did not kill the cells of the organism. Although Ezzouhri et al. [63] reported $10-15 \mathrm{mM}$ of $\mathrm{Cr}(\mathrm{VI})$ as the Minimum Inhibitory Concentration (MIC) for Aspergillus species, the results obtained however revealed that the response of the isolates to heavy metals depended on the metal tested, its concentration in the medium and on the isolate considered. They observed that various genera and also isolates of the same genus did not necessarily have the same heavy metal tolerance. Thus, variation in metal tolerance among fungal species may be due to the presence of one or more strategies of tolerance or resistance mechanisms exhibited by fungi.

\section{References}

1. Oliver DS, Brockman FJ, Bowman RS, Kieft TL (2003) Microbial reduction of hexavalent chromium under vadose zone conditions. J Environ Qual 32: 317 324

2. Gao Y, Zeng Q, Guo J, Cheng J, Ellis BE, Chen JG (2007) Genetic characterization reveals no role for the reported ABA receptor, GCR2, in ABA control of seed germination and early seedling development in Arabidopsis. Plant J $3: 1-10$

3. Khattar JIS, SarmaTA, Singh DP (1999) Removal of chromium ions by aga immobilized cells of the cyanobacterium Anacystis nidulans in a continuous flow bioreactor - a highly $\mathrm{pH}$ dependent phenomenon. Enzyme Microb Technol 25: $564-568$

4. Sani RK, Peyton BM, Smith WA, Apel WA, Petersen JN (2002) Dissimilatory reduction of $\mathrm{Cr}(\mathrm{VI}), \mathrm{Fe}(\mathrm{III})$, and $\mathrm{U}(\mathrm{VI})$ by Cellulomonas isolates. Appl Microbiol Biotechnol 60: 192-199.

5. Camargo FA, Okeke BC, Bento FM, Frankenberger WT (2003) In vitro reduction of hexavalent chromium by a cell-free extracts of Bacillus sp. ES 29 stimulated by $\mathrm{Cu}^{2+}$. Appl Microbiol Biotechnol 62: $569-573$.

6. Horton RN, Apel WA, Thompson VS, Sheridan PP (2006) Low temperature reduction of hexavalent chromium by a microbial enrichment consortium and a novel strain of Arthrobacter aurescens. BMC Microbiol 6: 5.

7. Li Y, Low GK, Scott JA, Amal R (2007) Microbial reduction of hexavalent chromium by landfill leachate. J Hazard Mater 142: 153-159.

8. Srivastava S, Ahmad AH, Thakur IS (2007) Removal of chromium and pentachlorophenol from tannery effluents. Bioresour Technol 98: 1128-1132.

9. Zetic VG, Stehlik-Tomas V, Grba S, Lutilsky L, Kozlek D (2001) Chromium uptake by Saccharomyces cerevisiae and isolation of glucose tolerance factor from yeast biomass. J Biosci 26: 217-223.

10. Kshminska H, Jaglarz A, FedorovychD, Babyak L, Yanovych D, et al. (2003) Bioremediation of chromium by the yeast Pinchia guilliermondii: toxicity and accumulation of $\mathrm{Cr}(\mathrm{III})$ and $\mathrm{Cr}(\mathrm{VI})$ and the influence of riboflavin on $\mathrm{Cr}$ tolerance. Microbiol Res 158: 59-67.

11. Poljsak B, Pocsi I, Raspor P, Pesti M (2010) Interference of chromium with biological systems in yeasts and fungi: a review. J Basic Microbiol 50: 21-36.

12. Niyogi S, Abraham TE, Ramakrishna SV (1998) Removal of $\mathrm{Cr}(\mathrm{VI})$ ions from industrial effluents by immobilized biomass of Rhizopus arrhizus. J Sci and Industr Res 57: 809-816.

13. Park CH, Keyhan M, Wielinga B, Fendorf S, Matin A (2000) Purification to homogeneity and characterization of a novel Pseudomonas putida chromate reductase. Appl Environ Microbiol 66: 1788-1795.

14. R SB, Abraham TE (2001) Biosorption of $\mathrm{Cr}(\mathrm{VI})$ from aqueous solution by Rhizopus nigricans. Bioresour Technol 79: 73-81.

15. Bai RS, Abraham TE (2002) Studies on enhancement of $\mathrm{Cr}(\mathrm{VI})$ biosorption by chemically modified biomass of Rhizopus nigricans. Water Res 36: 1224-1236.

16. Prasenjit, B, Sumathi S (2005) Uptake of chromium by Aspergillus foetidus. Journal of Material Cycles and Waste Management 7: 88-92.

17. Chardin B, Giudici-Orticoni MT, De Luca G, Guigliarelli B, Bruschi M (2003) Hydrogenases in sulfate-reducing bacteria function as chromium reductase. Appl Microbiol Biotechnol 63: 315 - 321

18. Bai S, Abraham TE (1998) Studies on biosorption of $\mathrm{Cr}(\mathrm{VI})$ by dead fungal biomass. J Sci and Ind Res 57: 821 - 824

19. Krauter P, Martinelli R, Williams K, Martins S (1996) Removal of Cr(VI) from groundwater by Saccharomyces cerevisiae. Biodegradation 7: 277-286.

20. Withers JM, Swift RJ, Wiebe MG, Robson GD, Punt PJ et al. (1998) Optimization and stability of glucoamylase production by recombinant strains of Aspergillus niger in chemostat culture. Biotechnol Bioeng 59: 407-418.

21. Shugaba A, Nok AJ, Ameh DA, Lori JA (2010) (a) Studies on the growth of some filamentous fungi in culture solutions containing hexavalent chromium. International Journal of Biotechnology and Biochemistry 6: 715-722.

22. Shugaba A, Nok AJ, Ameh DA, Lori JA (2010) (b) Bioremediation of hexavalent chromium and tannic acid in synthetic tannery wastewater using free and calcium-alginate immobilized spores and mycelia of Aspergillus niger and Aspergillus parasiticus. Bioremediat J 14: 142-149.

23. Shugaba A, Nok AJ, Ameh DA, Lori JA (2011) Studies on some growth related changes in cultures of Aspergillus niger and Aspergillus parasiticus treated with hexavalent chromium and tannic acid. International Journal of Biotechnology and Biochemistry 7: 251-264

24. Filipovic-Kovacevic Z, Sipos L, Briski F (2000) Biosorption of chromium copper, nickel, and zinc ions onto fungal pellets of Aspergillus niger 405 from aqueous solutions. Food Technol Biotechnol 38.

25. Ackerley DF, Gonzalez CF, Park CH, Blake R 2nd, Keyhan M, et al. (2004) Chromate-reducing properties of soluble flavoproteins from Pseudomonas putida and Escherichia coli. Appl Environ Microbiol 70: 873-882.

26. Acevedo-Aguilar FJ, Espino-Saldana AE, Leon-Rodriguez IL, Rivera-Cano ME, Avila-Rodriguez M, et al. (2006) Hexavalent chromium removal in vitro and from industrial wastes, using chromate-resistant strains of filamentous fung indigenous to contaminated wastes. Can J Microbiol 52: 809-815.

27. Desjardin V, Bayard R, Huck N, Manceau A, Gourdon R (2002) Effect of microbial activity on the mobility of chromium in soils. Waste Manag 22: 195200

28. Aksu Z, Egretli G, Kutsal T (1999) A comparative study for the biosorption characteristics of chromium (VI) on Ca-alginate, agarose and immobilized C. vulgaris in a continuous packed bed column. J Environ Sci Health 32: 295 - 316

29. Ackerley DF, Gonzalez CF, Keyhan M, Blake R 2nd, Matin A (2004) Mechanism of chromate reduction by the Escherichia coli protein, NfsA, and the role of different chromate reductases in minimizing oxidative stress during chromate reduction. Environ Microbiol 6: 851-860.

30. Balasubramanian S, Anuradha k (1999) Characterization of tannery effluents and the correlation between TDS, BOD and COD. J Environ Sci Health 34 $461-478$

31. Xu W, Hai C, Cheng Y, Gao S, Wang F (2006) A Novel Pumpkin Rich in Chromium Lowers Hyperglycemia and Enhances Translocation of Glut 4 in Alloxan-induced Diabetic Rats. J Med Sci 3: 1-10.

32. Munoz AH, CoronaFG, Wrobel K, Soto GM, Wrobel K (2005) Subcellula distribution of aluminium, bismuth, cadmium, chromium, copper, iron, manganese, nickel and lead in cultivated mushrooms (Agaricus bisporus and Pleurotus ostreatus). Biol Trace Elem Res 106: 265-277.

33. Trinci APJ (1972) Culture turbidity as a measure of mould growth. Transaction of the British Mycological Society 58: 467-473. 
Citation: Shugaba A, Buba F, Kolo BG, Nok AJ, Ameh DA, et al. (2012) Uptake and Reduction of Hexavalent Chromium by Aspergillus niger and Aspergillus parasiticus. J Pet Environ Biotechnol 3:119. doi:10.4172/2157-7463.1000119

34. Middleton SS, Latmani RB, Mackey MR, Ellisman MH, Tebo BM, et al. (2003) Cometabolism of $\mathrm{Cr}(\mathrm{VI})$ by Shewanella oneidensis MR-1 produces cellassociated reduced chromium and inhibits growth. Biotechnol Bioeng 83: 627 637

35. Gupta R, Ahuja P, Khan S, Saxena RK, Mohapatra H (2000) Microbial biosorbents: Meeting chanllenges of heavy metal pollution in aqueous solutions. Curr Sci 78: 967-973.

36. Yan G, Viraraghavan T (2000) Effect of pretreatment on the bioadsorption of heavy metals on Mucor rouxii. Water SA 26: 119-123.

37. Kapoor A, Vivraraghavan T (1998) Biosorption of heavy metals on Aspergillus niger: Effect of pretreatement. Bioresourc Technol 63: 109-113.

38. Gadd GM, White C (1989) Removal of thorium from simulated acid process streams by fungal biomass. Biotechnol Bioeng 33: 592-597.

39. Gadd GM (1990) Heavy metal accumulation by bacteria and other microorganism. Cell Mol Life Sci 46: 834-840.

40. Srinath T, Verma T, Ramteke PW, Garg SK (2002) Chromium (VI) biosorption and bioaccumulation by chromate resistant bacteria. Chemosphere 48: 427435

41. Francisco R, Alpoim MC, Morais PV (2002) Diversity of chromium - resistant and -reducing bacteria in a chromium - contaiminated activated sludge. J Appl Microbiol 92: 837-843.

42. Silver S, Walderhaug M (1992) Gene regulation of plasmid- and chromosomedetermined inorganic ion transport in bacteria. Microbiol Rev 56: 195-228.

43. Czako-Ver K, Batie M, Raspor P, Sipiczki M, Pesti M (1999) Hexavalent chromium uptake by sensitive and tolerant mutants of Schizosaccharomyces pombe. FEMS Microbiol Lett 178: 109-115.

44. Wang YT, Xiao C (1995) Factors affecting hexavalent chromium reduction in pure cultures of bacteria. Water Res 29: 2467-2474.

45. Bhat TK, Singh B, Sharma OP (1998) Microbial degradation of tannins--a current perspective. Biodegradation 9: 343-357.

46. Rodriguez H, de las Rivas B, Gomez-Cordoves C, Munoz R (2008) Degradation of tannic acid by cell-free extracts of Lactobacillus plantarum. Food Chem 107 664-670.

47. Mendonca E, Martins A, Anselmo AM (2004) Biodegradation of natural phenolic compounds as single and mixed substrates by Fusarium flocciferum. Electronic J Biotechnol 7: 30-34.

48. Alberto MR, Farias ME, Manca De Nadra MC (2001) Effect of gallic acid and catechin on Lactobacillus hilgardii $5 \mathrm{w}$ growth and metabolism of organic compounds. J Agric Food Chem 49: 4359-4363.

49. Fourest E, Roux JC (1992) Heavy metal biosorption by fungal mycelial products: Mechanisms and influence of pH. Appl Microbiol Biotechnol 37: 399-403.

50. Zhou JL (1999) Zinc biosorption by Rhizopus arrhizus and other fungi. App Microbiol Biotechnol 51: 686-693.

51. Upreti RK, Shrivastava R, Chaturvedi UC (2004) Gut microflora and toxic metals: chromium as a model. Indian J Med Res 119: 49-59.
52. Park D, Yun YS, Jo JH, Park JM (2005) Mechanism of hexavalent chromium removal by dead fungal biomass of Aspergillus niger. Water Res 39: 533-540.

53. Acevedo Aguilar FJ, Wrobel K, Lokits K, Caruso JA, Coreno Alonso A, e al. (2008) Analytical speciation of chromium in in-vitro cultures of chromateresistant filamentous fungi. Anal Bioanal Chem 392: 269-276.

54. Fukuda $\mathrm{T}$, Ishino $\mathrm{Y}$, Ogawa A, Tsutsumi K, Morita $\mathrm{H}$ (2008) $\mathrm{Cr}(\mathrm{VI})$ reduction from contaminated soils by Aspergillus sp. N2 and Penicillium sp. N3 isolated from chromium deposits. J Gen Appl Microbiol 54: 295-303.

55. Coreno-Alonso A, Acevedo-Aguilar FJ, Reyna-Lopez GE, Tomasini A Fernandez FJ, et al. (2009) $\mathrm{Cr}(\mathrm{VI})$ reduction by an Aspergillus tubingensis strain: role of carboxylic acids and implications for natural attenuation and biotreatment of $\mathrm{Cr}(\mathrm{VI})$ contamination. Chemosphere 76: 43-47.

56. Morales-Barrera L, Cristiani-Urbina E (2008) Hexavalent chromium removal by a Trichoderma inhamatum fungal strain isolated from tannery effluent. Water Air Soil Pollut 187: 327-336.

57. Ramirez-Ramirez R, Calvo-Mendez C, Avila-Rodriguez M, Lappe P, Ulloa M et al. (2004) $\mathrm{Cr}(\mathrm{VI})$ reduction in a chromate-resistant strain of Candida maltosa isolated from the leather industry. Antonie Van Leeuwenhoek 85: 63-68.

58. Sun F, Shao Z (2007) Biosorption and bioaccumulation of lead by Penicillium sp. Psf-2 isolated from the deep sea sediment of the Pacific Ocean. Extremophiles 11: $853-858$

59. Sintuprapa W, Thiravetyan P, Tanticharoen M (2000) A possible mechanism of $\mathrm{Zn}^{2+}$ uptake by living cells of Penicillium sp. Biotechnol Lett 22: 1709-1712.

60. Kermasha S, Pellerin F, Rovel B, Goetghebeur M, Metche M (1993) Purification and characterization of copper-metallothioneins from Aspergillus niger. Biosci Biotechnol Biochem 57: 1420 - 1423

61. Guest RK, Smith DW (2002) A potential new role for fungi in a wastewater MBR biological nitrogen reduction system. J Environ Engr Sci 1: 433-437.

62. Sani RK, Peyton BM, Brown LT (2001) Copper - induced inhibition of growth of Desulfovibrio dusulfuricans G-20: Assessment of its toxicity and correlation with those of Zinc and lead. Appl Environ Microbiol 67: 4765-4772.

63. Ezzouhri L, Castro E, Moya M, Espinola F, et al. (2009) Heavy metal tolerance of filamentous fungi isolated from polluted sites in Tangier, Morocco. Afr $J$ Microbiol 3: $35-48$.

64. Coulibaly L, Gourene G, Agathos NS (2003) Utilization of fungi for biotreatment of raw wastewaters. Afr J Biotechnol 2: 620 - 630 .

65. Sun F, Shao Z (2007) Biosorption and bioaccumulation of lead by Penicillium sp Psf-2 isolated from the deep sea sediment of the Pacific Ocean. Extremophiles 11: $853-858$

66. Gao H, Liu Y, Zeng G, Xu W, Li T et al. (2008) Characterization of Cr(VI) removal from aqueous solutions by a surplus agricultural waste- rice straw. $J$ Hazard Mater. 150: 446-452. 